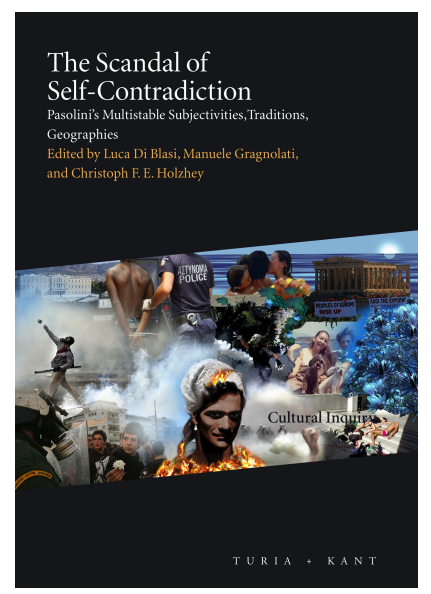

The Scandal of Self-Contradiction: Pasolini's Multistable Subjectivities, Geographies, Traditions, ed. by Luca Di Blasi, Manuele Gragnolati, and Christoph F. E. Holzhey, Cultural Inquiry, 6 (Vienna: Turia + Kant, 2012), pp. 167-86

PREVIOUSLY PUBLISHED AS:

| Identical except for DOI prefix 10.25620

\section{BERNHARD GROSS}

\section{Reconciliation and Stark Incompatibility \\ Pasolini's 'Africa' and Greek Tragedy}

CITE AS:

\begin{abstract}
Bernhard Gross, 'Reconciliation and Stark Incompatibility: Pasolini's 'Africa' and Greek Tragedy', in The Scandal of Self-Contradiction: Pasolini's Multistable Subjectivities, Geographies, Traditions, ed. by Luca Di Blasi, Manuele Gragnolati, and Christoph F. E. Holzhey, Cultural Inquiry, 6 (Vienna: Turia + Kant, 2012), pp. 167-86 <https: //doi.org/10.37050/ci-06_10>
\end{abstract}

RIGHTS STATEMENT:

(C) by the author(s)

This version is licensed under a Creative Commons AttributionShareAlike 4.0 International License.

ABSTRACT: Medea from 1969 is the completion and culmination of a series of Pasolini's films that engage with Greek tragedy. This series includes his film version of the Oedipus myth from 1967 and his reworking of Aeschylus's Oresteia into an African Oresteia from 1968. This film, Appunti per un'Orestiade africana, contains a sequence that is odd in a double sense. 


\title{
RECONCILIATION AND STARK INCOMPATIBILITY
}

\author{
Pasolini’s ‘Africa’ and Greek Tragedy
}

Bernhard Groß

Medea from 1969 is the completion and culmination of a series of Pasolini's films that engage with Greek tragedy. This series includes his film version of the Oedipus myth from 1967 and his reworking of Aeschylus's Oresteia into an African Oresteia from 1968. This film, Appunti per un'Orestiade africana, contains a sequence that is odd in a double sense. Approximately in the middle of this essay film - which seeks 'bodies and places' ${ }^{1}$ in various African countries for a contemporary Oresteia - Pasolini's voice, which has otherwise been commenting as a voice-over almost without interruption, breaks off. The images that we see at this point are not Pasolini's own footage, but documentary material from the so-called 'Biafra War', the Nigerian civil war of 19671970 - footage, as Pasolini explains before he stops speaking, that could come from conquered Troy. We see silent scenes of shootings, massacres, and plundering. The brutality of these shots is only experienced by the spectator through the muteness of the images. For it is only in this way that they are robbed of their function as news images, during which a commentary from off camera tells us what there is to see. In a certain sense, in Appunti per un'Orestiade africana, Pasolini imitates this hegemonic gesture by constantly looking for ways in which his shots might be useful for an African Oresteia. In relation to the film as a whole, one sequence, in which Pasolini discusses his film in Rome with African students, serves to relativize this gesture. And at the point in the film described here, Pasolini does something similar to what he had done in his first great essay film, La rabbia, from 1963. With the off sound or the original sound of the news images having been dropped out, only the 'naked' bodies are left behind: mistreated, killed, torn apart. If the narrative does not 'satisfy' the event, the physicality of the brutality is displayed.

Then an abrupt change in location takes place. Now the spectator finds himself or herself in a sound studio in Rome. We are watching, says Pasolini's voice off camera, the rehearsals for an Oresteia sung by two Afro-American singers; it is a jazz improvisation with the saxo- 

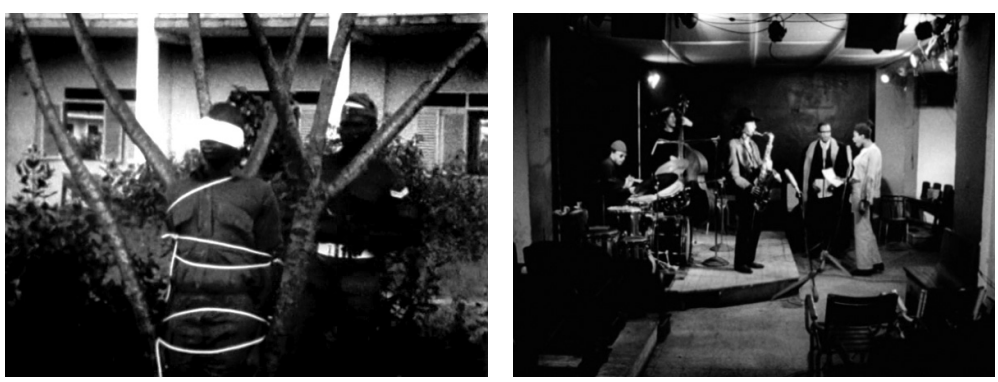

Fig. 1 + Fig. 2: 'Biafra War' and jazz rehearsal: film stills from P. P. Pasolini’s Appunti per un'Orestiade africana, I 1968

phone player Gato Barbieri (Fig. 2). The basic motif of this improvisation has already been heard a few times before, connected with Pasolini's shots of possible actors for the Oresteia. But now the source of the sound appears in the image for the first time.

Once again an abrupt change of scene takes place. Again we see brutal footage from Biafra, very similar to that shown before the jazz rehearsal (Fig. 1). And once again something has changed: for now the images are no longer silent, but are instead underscored by Barbieri's musical motif. The nearly unbearable crescendo of this music, which had developed before in the long sequence in the sound studio, becoming more and more atonal, now continues with a restrained saxophone solo - and takes on a peculiar quality as evidence along with the images.

If, previously, music scenes and documentary images collided harshly, now the relation between image and sound is different. If bringing in the music of the basic motif of the improvisation seemed to serve as background sound at the beginning of the film, now, in the way its contents link up with the brutal footage, it materializes into a musical lament, through which in turn the images definitively lose their compulsion to illustrate, because the goal of this aesthetic operation can now be seen. News images become scenes that lead the spectator to a place of pain and mourning. It is a place of aesthetic experience. Pasolini thus seeks to open up a site of possibility that does not exist in everyday life and which structures the whole film Appunti per un'Orestiade africana. So, like jazz and war in the scene described, in the film as a whole Western consciousness collides (in the commentator's observations) with the agrarian-proletarian reality of Africa, or, in 
other words, levels of sound and image collide. Their tertium comparationis thus forms Pasolini's engagement with classic Greek tragedy. But his goal in this, I would like to propose, is not any kind of historical reconstruction. ${ }^{2}$ Instead he investigates the 'originary texts' of the Western world and their performance practice for what their current political function might be, and this means asking which current questions of bourgeois life these texts can answer. In the case of Appunti per un'Orestiade africana this is specifically about the possibility of being able to understand contemporary political development in Africa, its contradictions and irrationalisms, from an European perspective. For Pasolini, this only seems to be possible by going back to the originary texts of the Occident, in this case Aeschylus's Oresteia, and crossing them with African reality. This is due, in my opinion, to the fact that classical Greek tragedy is the aesthetic site where things that are incompatible in human life can brusquely come together, such as jazz and war here, or African reality and European gaze.

In order to understand how and why Pasolini proposes this relation of Europe, Africa, and Greek tragedy, we will need to look at his next film, Medea.

\section{ANTAGONISTIC CONFLICT}

The 'Africa' of this film is called Colchis. But this 'Africa' is terra incognita - it is viewed completely without mediation. The aesthetic experience in Medea is more related to tragedy as the site of an irresolvable antagonistic conflict. The cathartic effect of tragedy drops into the background. How does Pasolini come to such an intense and dynamic engagement with Greek tragedy? Why does it seem to form the matrix for his concern with contemporary problems in Africa and Europe? Appunti per un'Orestiade africana and Medea are the two poles between which the political battle around 1968 played out. And thus it is possible to create a connection between the way myths were reworked or updated and the changes in society. At the time of Medea, at least, the student protests and bourgeois revolts had already passed their peak. The reference to these events is clearly produced as iconography. In Medea the Argonauts are bourgeois beatniks and the people of Colchis are peasants in festival costumes (Fig. $3+4$ ). 

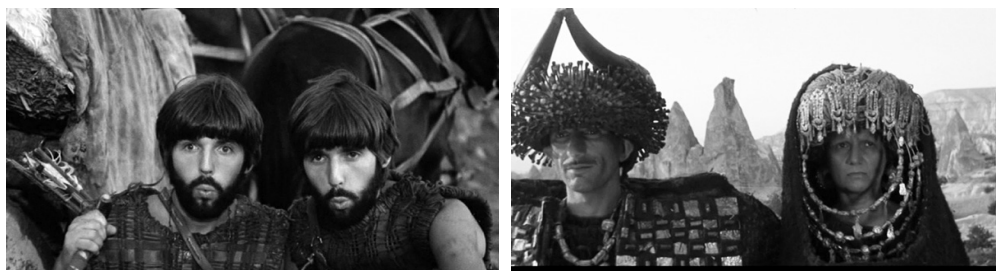

Fig. 3 + Fig. 4: Argonauts and people of Colchis: film stills from P. P. Pasolini's Medea, I 1969

The point of my drastic formulation is to clarify that this antagonistic conflict is realized in the spectator's film experience. The camera's gaze puts the spectator into a position in which the only possible view is a bourgeois one, one that maintains an ironic distance in how it views ${ }^{3}$ the world that the film unfolds. The viewer looks at Colchis with the eyes of the Greeks and is mirroring himself in the gaze of the Greeks.

Medea is inscribed with Italy's culture shock between 1955 and 1965 , which had precipitated the country out of an agrarian period and into the industrial age; this is why the film does not explain, but unfolds, piece by piece, the antagonistic conflict of two incompatible positions: Jason's world and Medea's world - one subjective and the other objective, one secular and the other mythical. This rigid constellation of gazes only dissipates when Jason and Medea find each other.

Medea's entry into Jason's world means losing her social integrity. The public figure, queen and sorceress, becomes a 'private' character, mother and housewife, who increasingly disappears from view because official order demands it. The film turns this into the experience of an irresolvable dilemma. The classic form of this dilemma is a certain way of reading ancient Greek tragedy, which I will now explain. My thesis is that it is an understanding of tragedy in terms of the aesthetics of effect that forms the foundation for Pasolini's 'films of antiquity'.

In order to demonstrate this thesis, I would first like to place Pasolini's films in the wider context of his engagement with Greek tragedy. Then I will explore the question of the timeliness of Pasolini's understanding of tragedy. Finally I will analyze the specific cinematographic engagement with this understanding - that is, the staging of a world of incompatible oppositions - above all in Medea. By refering back once again to Appunti per un'Orestiade africana at the conclusion, it should become clear that the female characters in Greek tragedy play a particu- 
lar role in this world of brusque oppositions. As Pasolini stages them, they form the aesthetic site at which the incompatible and the contradictory can be experienced.

MEDIA CROSSING

Pasolini's works can be presented, from the earliest dialectical poetry from the 1940s through the literature, theatre, and films of the 1950s to 1970s, as a gradual unfolding of image spaces, ${ }^{4}$ that is, of opticalacoustic constellations, which mark the poetic operations from the very beginning. What guarantees this development is a crossing of the media themselves, which mutually interrogate the possibilities and boundaries of their ways of representing. From the very beginning of his artistic activity, Pasolini's poetry and literature work out their themes cinematographically, while his cinema engages with the problems of literature or even dramatic theory. One can therefore speak of a genealogical construction in which poetry becomes the axiom of prose, prose the axiom of film, film the axiom of literature and the theatre, and the theatre in turn the axiom of film, so that each one of these arts is reflected in another medium and stretches its boundaries. ${ }^{5}$ Seen in this way, even Greek tragedy and the keyword 'Africa' belong to this axiomatic structure. In view of the theatre, film becomes alien; in view of Africa, Europe does.

THEATRE AS THE 'SENSORIUM' OF THE CINEMATOGRAPHIC TRANSFORMATION OF CHARACTERS ${ }^{6}$

On the basis of this axiomatic structure, Pasolini reaches a fundamental paradigm shift in the middle of the sixties. From then on, instead of being concerned with the subproletariat, Pasolini turns to the bourgeoisie. Until 1965, the constant engagement with the problem of representing a subproletariat, incommensurable and excluded from society and history, is the driving factor behind creating audiovisual image-spaces, which, across all genres and media, time and again propose new constellations of the relationship between gaze and voice in order to pose the question of the possibility of the political as aesthetic experience. After 1965, the bourgeoisie comes to the fore in all its forms: if, until 
1965, Pasolini's cosmos is filled with subproletarian characters whose vanishing point and matrix is represented by Jesus Christ, afterwards he is concerned with all facets of bourgeois life: be it with the petite bourgeoisie in Uccellacci e uccellini (1965) or with the haute bourgeoisie from Teorema (1968) up to Medea. Within this framework, several plays for the theatre were also produced over a short period in $1966 ;^{7}$ they often took up the topic of ancient Greek tragedy. The engagement with the theatre becomes a theoretical foundation for Pasolini's concern with the bourgeoisie in his films after 1965. The theatre is the medium for this negotiation, just as film had previously been for his concern with the subproletariat.

The consistent poetic principle in Pasolini is thus the development, in each case, of a specific aesthetic 'sensorium' for everything that is not covered in the general consciousness of reality, that is, everything that is not common sense. ${ }^{8}$ This poetics can be understood in reference to the currently most advanced theories of a 'politics of art' by Jacques Rancière, because, as in Rancière, it has no fixed political terms, instead locating the political in art in a constant process of questioning, demonstrating, and making visible a per se heterogeneous world, and thus one that is never accessible in its entirety.

Rancière understands art as a temporal and spatial arrangement that takes the spaces occupied and distributed by classical politics and reconstructs or deconstructs them, varies and thwarts them, redistributes or reoccupies them. Contrary to the definition of political art as the representation or illustration of a political idea, he understands this as experience:

Art is not political owing to the messages and feelings that it carries on the state of social and political issues. It is not political owing to the way it represents social structures, conflicts or identities. It is political by virtue of the very distance that it takes with regard to those functions. It is political as it frames a specific space-time sensorium, as it redefines on this stage the power of speech or the coordinates of perception, shifts the places of the actor and the spectator, etc. Because politics is not the exercise of power or the struggle for power. Politics is first of all the configuration of a space as political, the framing of a specific sphere of experience, the setting of objects posed as 'common' and subjects to whom the capacity is recognized to designate these objects and argue about them. [...] [P]olitics first is the conflict about the very existence of that sphere of experience, the reality of those common objects and the capacity of those subjects. ${ }^{9}$ 
Reading this description, one can almost not help thinking of the cinema as the medium of organizing space and time. There seems to be an understanding of cinema inscribed here as it developed after the Second World War: a cinema that organizes perception above all as aesthetic experience and thus makes it possible to view an impermeable and misaligned reality. ${ }^{10}$ The search for a seismography that - in the tradition of such a cinema of perception, the example par excellence of which is, for Bazin and Kracauer, Italian neorealism - would make it possible to perceive and experience reality at all, namely as something constantly changing rather than simply accessible, forms the backdrop for the change of the cosmos of characters in Pasolini's films from the middle of the 1960s. For by then the political, social, and economic conditions in Italy had fundamentally transformed.

\section{'MANIFESTO PER UN NUOVO TEATRO'}

For his engagement with the bourgeoisie, Pasolini therefore looks with the theatre to the cinema and his films. This central valuation of the theatre as an axiomatic structure, from the second half of the 1960s, becomes clear above all if we read Pasolini's Manifesto per un nuovo teatro, also written in the middle of the sixties. ${ }^{11}$

This polemical text is aimed against both traditional bourgeois theatre and experimental theatre. Both are seen as stuck in representation the one in a 'culinary' system, ${ }^{12}$ the other in the idea of liberation and immediacy. According to Pasolini, political theatre is about neither entertainment nor authenticity, and certainly not about agitation of dialectics: 'I tempi di Brecht sono finiti per sempre.' ${ }^{\text {13 }}$

In opposition to this understanding of theatre, Pasolini seeks to develop what he calls the teatro di parola ${ }^{14}$ a performance practice of theatre that is primarily about creating a place in which a self-understanding of the intellectual bourgeoisie can take place: an understanding about everything that is socially excluded and marginalized - sickness and death, madness and drugs, sexuality and perversion, etc. These may be the typical topics of the ' 68 generation, but here they are understood as a problem of art: precisely that of creating a place where these topics can be negotiated, without leading to the hospital, the jail, or the madhouse. One can therefore understand this theatre as the counterpart to Pasolini's Roman novels and his early films. The novels and early films 
present a subproletarian world that presents an outside beyond all social conventions. The Manifesto per un nuovo teatro represents the complementary attempt to make it possible to experience what is inaccessible to the bourgeois world through an elite theatre of discussion as a space of democratic engagement. The theatre is understood - explicitly against the neo-avant-garde theatre of the sixties, e.g. Julian Beck and Judith Malina's New York Living Theatre - as a place where a selfunderstanding becomes possible through what is excluded from bourgeois society.

Pasolini's plays for the theatre thematize what is excluded, as do the plays that he wished to see performed in his teatro di parola: namely ancient Greek tragedies. What Pasolini has in mind is a contemporary theatre that would have a similar political function to that of the theatre of antiquity for the Greek polis. When I speak of ancient Greek theatre, I mean classic theatre, above all from the fifth century BC (from Aeschylus to Euripides), in which theatre takes on a preeminent standing within the social structures of the polis as an aesthetic practice, as Theo Girshausen has demonstrated in reference to Jean-Pierre Vernant. ${ }^{15}$ Pasolini refers to this social function with his idea of a democratic theatre of dialogue, a theatre of the word in the emphatic sense. In this aesthetic space, what gets heard are the voices that could negotiate what would be unthinkable in everyday life. The reference to antiquity is not about a proximity of theatre and democracy, but about a distance between the two. In particular, the performance practice of Greek tragedy facilitates an (aesthetic) experience that takes up everything that is not negotiable as everyday experience in the social space of the polis.

\section{THE POLITICS OF ANCIENT GREEK TRAGEDY}

This, at least, is how Theresia Birkenhauer, in her essay 'Tragedy: Working on Democracy', reads the function of ancient Greek tragedy in relation to its performance practice - that is, the architecture of the theatron ${ }^{16}$ At the same time, Birkenhauer declares the existence of a lack in the current understanding of tragedy, which this practice can reveal. For it is not the heroes who gain a moral victory through their defeat, and in the end Greek tragedy is not about resolving antagonistic conflict. What tragedy unfolds and makes space for is a principle of contradiction, which the audience can only negotiate in the aesthetic play: 
By drawing attention to the differences, to the in-between-spaces between what is said and what is not said, what is shown and what is not shown, tragedy extends the area of what can be thought and represented. In this way, tragedy develops a space of possibility. The scene of the theatre is $[\ldots]$ a fictional space where antagonistic conflicts can be visualized in the play that in reality would be unbearable for the people. ${ }^{17}$

Theatre thus would become a site of possibility where the polis could find a place to speak about the most painful and most unspeakable aspects of life - an idea that, according to Birkenhauer, is unimaginable in today's 'dictatorship of consensus'. These days, Greek tragedy is wrongly understood as a representational organ of parliamentary democracy. This understanding of the role of democracy in tragedy excludes the 'invisible structural conditions of violence' and thus has little in common with the function of the Greek tragedy for the polis. ${ }^{18}$ The purpose of this function is to depict, 'in the space of the play, under the non-ambiguities of the religious and the political, the deep ambiguities of the realness, which people, in life, can disrupt'. ${ }^{19}$ In this way of reading, what can make it possible to experience Greek tragedy aesthetically is not the already known, the otherwise accessible, but precisely what is invisible and unbearable in the contexts of social life.

I would now like to claim that Pasolini makes this political function of tragedy into a matrix, above all in his Medea film, by proposing a specifically cinematographic space of experience, which I have already suggested in the case of his Appunti per un'Orestiade africana, and which unfolds the fundamental antagonistic conflict of tragedy, the 'deep ambiguity of the realness', ${ }^{20}$ by constructing cinematographic regimes of gazes. The consciousness of the acuity of this antagonistic conflict thus becomes visibly clear again as the current experience of the loss of the social in the aesthetic process. Medea could then be equated with the role of the performance practice of ancient Greek tragedy, as Birkenhauer described it. With this conceptual definition of the function of Greek tragedy, we can now be more precise in defining why Pasolini goes back to ancient material in an effort to come to terms with a current social problem.

What would this antagonistic conflict be in the case of Medea? In Euripides's tragedy it is a matter of the difficult relationship between public and private morality: it is about marriage and love, fidelity and betrayal. Pasolini, however, also leads this antagonistic conflict between 
the secular and the mythical world, between the male and the female world. Jason and Medea are their agents. The painful 'ambiguity of the realness ${ }^{21}$ emerges at the moment in which the two worlds collide with each other.

\section{THE INCOMPATIBILITY OF THE WORLDS}

At the beginning of Medea, Jason's intimate world and Medea's public world are presented. If in the one it is about individuality in a secular world, in the other it is about collective life in myth. But the confrontation of the secular and the mythical world precisely does not function because Pasolini assigns his protagonists to one world or the other, for love runs into conflict with the laws of both worlds. What Pasolini adds to the debate is more the materiality of the gaze at these worlds. Thus he transforms the spectator - as in his teatro di parola - directly into the center of the engagement with the subject matter. This is because the film presents ambiguity and disruption, which Greek tragedy thematizes, as the spectator's experience. Over the course of the film, then, the spectator is confronted with the gazes from two worlds that cannot be synthesized.

This can be described already in relation to the film's first sequence, which briefly presents Jason's childhood. It begins with an idyll. But Jason's expulsion has already begun with the first words spoken by the centaur Chiron, an expulsion from a world that is sacred because everything in it has its fixed place. And thus Jason's gods-given world ends on his fifth birthday: Chiron announces to the boy that he does not belong to this sacred world, that he is a foster child and Chiron is not his father, but a liar. The myth that he then tells Jason about his origins is completely foreign to the child.

In the following sequence, when Chiron conjures up the sacredness of the landscape in which he is embedded, we can already see in Jason's reactions that what the centaur means by this is an understanding of the world no longer based on any personal experience; for Jason the myth is simply a story. He falls asleep while the centaur is speaking, later playing with a crab instead of turning to the sacred earth, as Chiron has insistently demanded of him. Jason does not see himself embedded in this world, he simply lives an intimate but dull life with a talking horse. 


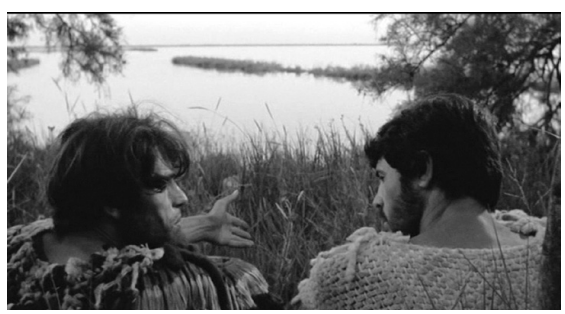

Fig. 5: The centaur Chiron and his foster son Jason: film still from P. P. Pasolini's Medea, I 1969

In the engagement with the myth that the centaur represents, a second gaze comes to be, which is quite incompatible with the myth. It is Jason's instrumental gaze, which the spectator finds it hard to pull away from, because it is developed out of the 'innocent gaze' of a child. Over the course of the process of separating from Jason, the centaur finally looks at the ancient myth from a modern perspective, as enlightened as Jason looks at Chiron, who in the end is no longer a mythical creature, half man, half horse, but appears quite profanely as a man. The highpoint of this development and the quintessence of Chiron's speech are found in the last shot of the sequence.

While he describes the end of a pantheistic world, the spectator looks with him and Jason over both shoulders into that world (Fig. 5). With this subjective shot it becomes abruptly clear what it means when everything becomes profane: the objective gaze, the gaze from outside, the gaze from a third lookout, gets lost - and with it the basis of Pasolini's former poetics of the heterogeneous. ${ }^{22}$

This subjective shot in Medea is so meaningful because it is one of the very few subjective shots in Pasolini's films at all. Until 1964 there is not a single such shot, for the distinguishability of the perspective of character, camera, and narrator - as these facilitate free indirect discourse or sogettiva libera indiretta, analogously developed by Pasolini in the cinema ${ }^{23}$ - is one of the fundamental aesthetic operations. Pasolini uses it to make it possible to experience not only the heterogeneity of what is represented, but also the potential of the realness. The mythologizing of the profane, the metamorphosis of the subproletariat into sacred figures in Pasolini's novels from the 1950s and in his films from the 1960s, presumes this gaze from outside, in which the charac- 
ters then unfold. Now, however, when the gaze of the camera and that of the character have become one, the foundation for Pasolini's aesthetic operation is missing. Appunti per un'Orestiade africana still attempts to tackle this problem with the foreign, that is, the Europeanbourgeois gaze on Africa. Medea simply unfolds this dilemma.

\section{REGIMES OF THE GAZE}

In Medea, such a subjective and possessing gaze defines Jason's world. From here on - just as the centaur had told him - both he and the spectator no longer see the sacredness of the world, but its literal beauty: the hero, brimming over with virility, who, even in the most difficult situations, sees and at the same time relates himself to the beauty (and therefore the sex appeal) of the servant girl as well as that of the foreign queen. He flirts with them, like the wild horses of Colchis, until he has captured them (Fig. 6).

With the gaze of the people of Colchis things are different. This is where the sacred world is seen, which the centaur had previously only evoked. For the camera's gaze is foreign in the face of what is staged before the camera. For Pasolini it is not a matter of any ethnographic view to the events. What is staged before the camera is an eclectic conglomeration of the characters, their costumes, the plot, and the landscape: an artefact. A gaze does indeed unfold, but its instrumental relation to the world runs aground. Everything is visible, but the 'rite' by which the film creates a kind of magical mood for the spectator still cannot be explained. This magic is not part of the plot, it is a mode of representation. The 'ambiguity of the realness' is here seen in the simultaneity of the staging of, on the one hand, sober and distant observation (to which the festival costumes mentioned above belong - that is, the documentary-style exhibition of characters placed into grotesque costumes) and, on the other, the evocation of this magical mood. Put in formal terms, the difference between the mythical and the secular world can be formulated as 'the life of the people of Colchis is horrible but fascinating'; 'the life of the 'Greeks' is pleasant, but boring'. It is from this position that the spectator watches the story of Jason and Medea. That is, he looks at the difference between Jason's world and that of Medea. It marks the height from which the heroine must fall when she starts to get involved with Jason (and in a certain way the opposite is 


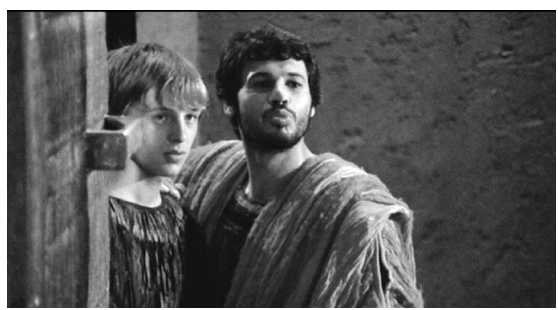

Fig. 6: Jason in Corinth, throwing Medea a kiss: film still from P. P. Pasolini's Medea I 1969

also true). In Colchis, Medea is a public figure par excellence, an irreplaceable part of a ritual world, queen and sorceress at once.

For the characters, the tragedy begins at the very moment in which Medea loses herself into Jason's possessing gaze. In Jason's subjective gaze, Medea sees her own desire mirrored back and discovers a completely new world in recognizing the possibility of a subjective gaze. This transformation is marked by the subjective perspective with which Medea suddenly looks at the Golden Fleece. She sees it as an animal pelt full of lice, and tearing it down and carrying it off is just a job to do. This new approach to the Fleece is no longer comparable to the martyrdom that it used to mean for her just to come near this holy of holies. She was herself spat upon and had to run through fire in order to get to the temple at all - the temple in which the Golden Fleece, the spiritual center of the world for the people of Colchis, was kept. In the theft scene, Maria Callas's acting loses everything that distinguishes her from the character of Jason: the declaimed heroine, subject to a fixed, coded repertoire of gestures, turns into the type embodying the role (like Jason). Medea's movement, gestures, and facial expressions are now marked by the subjective endeavor of having to act in a dress that is like armor and is much too cumbersome. So it is not Medea's magical powers that help Jason to steal the Golden Fleece. It is the gaze of instrumental reason to which Medea adapts herself which gives her a power unknown in her world and which finally captures and encompasses her in the spectator's gaze as well. For along with the change in worlds, she also transforms from a queen to a literally clumsy character in the eyes of the spectator.

From now on, what is achieved in the staging of the character is the antagonistic conflict between objective and subjective gaze, between 
secular and sacred world, between intimacy and publicness. In this battle, Medea begins to disappear. Without the public function that she occupied in Colchis, and without magic, Medea shrinks more and more into the role of an aging mother and housewife, whose grotesque clothing appears to the spectator (as that of the people of Colchis had before) as folklore. Now, in this world of explanations, assurances, and intrigues, she is a character without a voice. ${ }^{24}$ She had also been this in Colchis, but there her lack of voice was part of her magical power. She is a stranger, foreigner, outsider, and woman, above all because - voiceless as she is - she stands between the two regimes of the gaze, which unfold through the character. The film finds a refrain-like repetitive structure for this 'ambiguity of the realness' ${ }^{25}$ The film locates this repetitive structure at a point when Medea has long been at home in Corinth under arrest. Once again we see Medea's dream sequence, which is mirrored by a scene depicting a new encounter between Jason and the centaur Chiron in Corinth. ${ }^{26}$

\section{MEDEA AS SORCERESS AND HOUSEWIFE}

In this dream sequence, Medea gets her feared magical powers, which characterized her life in Colchis, back through a pact with the elements: fire, water, air, and earth. In what follows, just as it is told in the myth, she gives her children the wedding dress prepared for Glauce. As soon as Glauce puts it on, she burns up inside it, and her father, King Creon, who had come to help her, also burns along with her.

In the repetition of this sequence, however, the pact with the elements is missing. Instead, she is banished from the country by Creon, after which she faints. When she wakes up again, the whole disruption that the film thematizes through the character is revealed. She sleeps with Jason one more time; then the same sequence is repeated: the children present the wedding dress once again, but this time Glauce doesn't burn, she throws herself off a tower after having looked at herself in the mirror and at her father one last time. Her father jumps after her.

The outcome is then not magical murder, but double suicide. It is not the mythical world, the order of which unfolded bit by bit at the beginning in Colchis, that comes back here, but the profane world of individual minds is shown. Ritual logic has become psychological causality, myth has become a transparent story. ${ }^{27}$ Everything can be 


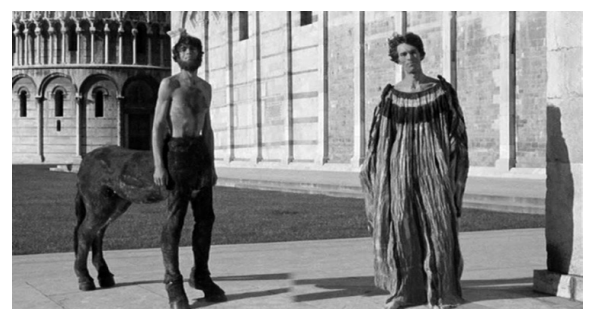

Fig. 7: Chiron as centaur and as man in Corinth: film still from P. P. Pasolini's Medea, I 1969

explained in this world. The 'depressive' Glauce cannot bear being clothed in her predecessor's wedding gown, her father cannot bear the guilt over his daughter's death - so they jump to their deaths, one after the other.

The explanation for this profane world had already been given by the centaur, when Jason chanced to meet the profane and the mythical figure, the man and the horse, after many years in Corinth (Fig. 7). He, Jason, sees the mythical figure and the man at the same time because the old, mythical centaur calls up the feeling that the new, secular one speaks of and explains.

Medea's 'curse' therefore lies in the fact that, landing in this world of the subjective gaze, of desire, and of love, she has transformed into a private person whose public appearance is forbidden and whose voice is not heard. Her problem is treated as private - so, unlike all other protagonists, she is shown as an isolated figure, starting with the return from Colchis. What the film thus exposes is the agonizing experience of a woman crossing the border between a world of all-encompassing perception and a world of causal behavior. And the spectator stands with her between a world in which he 'sees' everything, but cannot 'do' anything or 'explain' anything, and a world in which he can 'explain' everything but cannot 'see' anything. The tragedy of the character thus becomes - in the sense of the aesthetic effect of the function of tragedy for the polis, as Birkenhauer describes it - the direct film experience of the spectator.

Medea makes this dilemma visible by producing fire-'light' and by raising her voice unmistakably. She screams out the murder of her children and sets fire to her house - thus literally becoming a public per- 


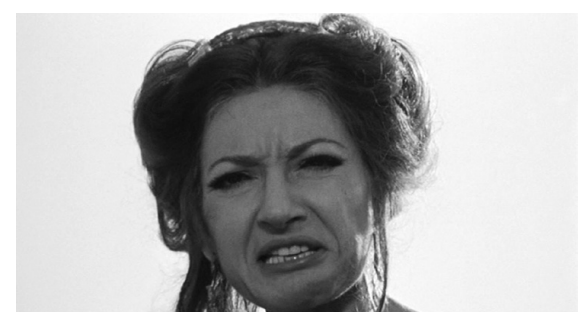

Fig 8: Maria Callas as Medea in the final sequence: film still from P. P. Pasolini's Medea, I 1969

son. Without a house, which has become a torch, she becomes visible from a great distance, furiously united with the elements, as the final image shows Medea grimacing in the blazing fire (Fig. 8). But her revenge is also cool and calculated. She obliterates her husband's possessions. Her raving exceeds any psychology. She calls up feelings that can no longer be explained. But through this she once again becomes a public figure (and a myth) in a world that is instrumentalized through and through. The declamations of the heroine or feminine affects define the final image. ${ }^{28}$ In the end, Medea becomes the embodiment of the function of Greek tragedy: she unites the incompatibility of Colchis and Corinth, of love and 'bourgeois life', of social role and individual desire and makes this incompatibility visible in the process.

Starting from this point, one can also cast a fresh glance again at Appunti per un'Orestiade africana. Here as well the female characters play a central role for the understanding of 'African reality' and European gaze. The female characters in this film mark what is getting lost or could get lost (and in the case of Medea has been lost), in the 'democratizing of Africa' and what is thus relegated to the blind spot of the bourgeois world of Europe, which Pasolini announces with his teatro di parola. It is the unpredictable, the resistant, or even the ambiguity of life, which, as Birkenhauer argues, cannot be eliminated, but only suppressed, even and especially by a democratic state. Like in Medea, in Appunti per un'Orestiade africana this figuration also turns up in the female characters. It is, indeed, Pasolini's voice that in the end negotiates the transformation of the Erinyes into Eumenides; we see the signs of "progress" in the form of a university and a court, but the female characters who appear before the camera - and this is also clear and 


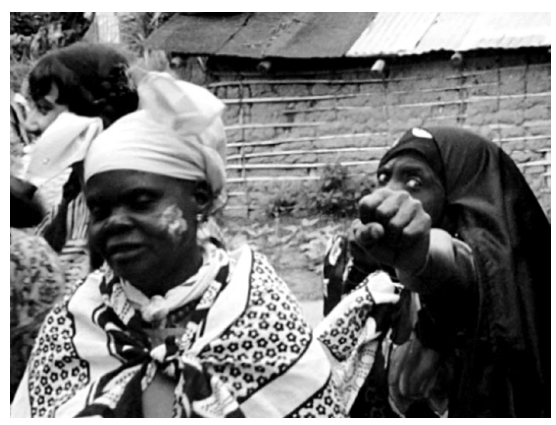

Fig 9: Film still from P. P. Pasolini's Appunti per un’Orestiade africana, I 1968

works against the level of sound in the film - will literally not budge an inch, not in front of the camera and not in front of the strategies of gratification attempted by politics (Fig. 9).

Here, the price of bourgeois democracy, the contempt for the marginal in majority consensus, can be experienced because place is given to this marginality, a location of antagonistic conflict and ambiguity of the realness, as Pasolini's voice formulates in the final sequence of the film using the term 'co-existence': 'Le furie si lasciano convincere dalle parole di Atena e accettano di coesistere con lei, la dea della ragione, esse, le dee dell'irrazionalità, nel nuovo mondo indipendente, democratico e libero.'

Co-existence describes the site at which the 'ambiguity of the realness, that people, in life, can disrupt', can take place as aesthetic experience. ${ }^{29}$ Pasolini thus not only crosses the contemporary political situation in Africa with Greek tragedy in order to create a site of mourning, which the images from the television news had eliminated (as I formulated it at the beginning of my text). He also updates a function of this tragedy, which the bourgeois European view sees as blocked, and opens it up so that it can be experienced. The understanding about contemporary Africa and its ancient counterpart, in the name of Colchis, is thus first and foremost a self-understanding of the 'enlightened bourgeoisie', as Pasolini's Manifesto per un nuovo teatro proposes. Pasolini's 'Africa' in the form of Greek tragedy creates exactly the aesthetic site from which it becomes possible to see, and thus to experience, Western Europe's blind spot. 


\section{NOTES}

1 This is the subtitle of an essay by Karsten Witte on the staging of corporeality in Pasolini's films. See Karsten Witte, 'Das Erfinden einer neuen Schönheit: Pasolini - Körper/Orte', in Die Körper des Ketzers: Pier Paolo Pasolini (Berlin: Vorwerk 8, 1998), pp. 54-75.

2 The theoretical and historical problems of dramatic tradition have been analyzed in a brilliant study on the theatre of antiquity by Theo Girshausen. See Theo Girshausen, Ursprungszeiten des Theaters: Das Theater der Antike (Berlin: Vorwerk 8, 1999), pp. 10-16.

3 As a 'class conscious' artist, Pasolini pursued his created work from the beginnings according to a politics that asked how it is possible to give the 'people' a voice. As a 'Marxist poet' and later a filmmaker in the Gramscian tradition, Pasolini was never satisfied with forms of 'socialist realism'. For him it was always a matter of making visible the problems between 'bourgeois author' and proletarian character. I have attempted to provide a describe the aesthetic operations associated with this as thoroughly coherent in poetry, prose, film, theatre, and essay in Bernhard Groß, Figurationen des Sprechens: Pier Paolo Pasolini (Berlin: Vorwerk 8, 2008).

4 I understand film image-spaces as distinct from film plot-spaces, in which the cinematographic operations serve as effects of narration, as complex audiovisual processes, which are realized in the spectator and unfold to him as an experience of aesthetic projections of worlds. Hermann Kappelhoff uses the term and refers with it to Walter Benjamin. The published translation of this term in Benjamin's work is 'image space', which I employ here. See Hermann Kappelhoff, 'Narrative Space - Plot Space - Image Space' available at <http://www.hermann-kappelhoff. de/01/images/stories/narrative_space_onlineversion.pdf $>$ [accessed 26 September 2011].

5 This is the main thesis of my book on Pasolini. See Groß, Figurationen des Sprechens.

6 See Massimo Fusillo, La Grecia secondo Pasolini: mito e cinema (Roma: Carocci, 2007) and Edi Liccioli, La scena della parola: Teatro e poesia in Pier Paolo Pasolini (Firenze: Le Lettere, 1997).

7 These are Porcile, Orgia, and Bestia da Stile, as well as Affabulazione, Pilade, and Caldéron.

8 See Jacques Rancière, The Politics of Aesthetics: The Distribution of the Sensible (London: Continuum, 2009).

9 Jacques Rancière, 'Aesthetics and Politics: Rethinking the Link', talk at the University of California at Berkeley, September 2002. Available at <http:// www.16beavergroup.org/monday/archives/001881.php > [accessed 11 September 2011].

10 I am referring here to the positions of André Bazin and Siegfried Kracauer. Compare André Bazin, What is Cinema?, ed. by Hugh Gray (Berkeley: University of California Press, 1971), and Siegfried Kracauer, Theory of Film: The Redemption of Physical Reality (Oxford: Oxford University Press, 1965). 
11 Pier Paolo Pasolini, 'Manifesto per un nuovo teatro', in Teatro (Milan: Garzanti, 1995), pp. 711-32. See also David Ward, 'Pier Paolo Pasolini and the Events of May 1968: The "Manifesto per un nuovo teatro", in Pasolini Old and New. Surveys and Studies, ed. by Zygmunt G. Bara ski (Dublin: Four Courts Press, 1999), pp. 321-44, as well as Jutta Linder, Pasolini als Dramatiker (Frankfurt am Main: Lang, 1981).

12 I refer to Brecht's term. Compare Bertolt Brecht, 'The Modern Theatre is the Epic Theatre', in Brecht on Theatre, ed. and trans. by John Willett (New York: Hill and Wang, 1964), pp. 33-42 (p. 35).

13 Pasolini, 'Manifesto per un nuovo teatro', p. 714.

14 Ibid., p. 715.

15 Cf. Girshausen, Ursprungszeiten des Theaters, pp. 361-70.

16 Theresia Birkenhauer, 'Tragödie: Arbeit an der Demokratie. Auslotung eines Abstandes', Theater der Zeit, 11 (2004), pp. 27-28. See also her Theater/Theorie: Zwischen Szene und Sprache, ed. by Barbara Hahn and Barbara Wahlster (Berlin: Vorwerk 8, 2008).

17 Birkenhauer, Tragödie: Arbeit an der Demokratie, p. 27. Compare Girshausen, Ursprungszeiten des Theaters, pp. 370-92.

18 Birkenhauer, Tragödie: Arbeit an der Demokratie, p. 27.

19 Ibid., p. 28.

20 Ibid.

21 Ibid.

22 In this figuration, one can no doubt recognize a commentary on the period around 1968. It suggests the familiar idea on the culture industry, which levels all social differences by subsuming them to the consumer. Pasolini, however, relates this critique of capitalism to the protesters themselves, by present Jason and his Argonauts in the habitus and appearance of beatniks, and the Argonauts' journey as an adventure trip. The formation of the characters is similar in Teorema and Porcile from 1968/69. And in Edipo re, Pasolini's first 'film of antiquity,' it is the psychic type - the covert mama's boy - who returns to his homeland, the site of his primal scene.

23 See Pier Paolo Pasolini, 'Il "cinema di poesia"', in Empirismo eretico: Saggi (Milan: Garzanti, 1981), pp. 167-87, (p. 183). See also Gilles Deleuze, Cinema 1: The Movement Image, trans. by Hugh Tomlinson (London: Athlone Press, 1986), pp. 72-73, as well as Silvia Carlorosi: 'Cinepoiesis: The Visual Poetics of Pier Paolo Pasolini, Michelangelo Antonioni and Franco Piavoli’ (unpublished doctoral thesis, University of Pennsylvania, 2006), pp. 22-23.

24 En passant, Pasolini thus stages the drama of Callas in reverse. Her magic consisted precisely in the fact of having a 'divine voice'.

25 Birkenhauer, Tragödie: Arbeit an der Demokratie, p. 28.

26 On the meaning of the dream structure, see Luca d'Ascia, 'Die Genealogie der Macht bei Pier Paolo Pasolini', in Kunst-Macht-Gewalt: Der ästhetische Ort der Aggressivität, ed. by Rolf Grimminger (Munich: Fink, 2000), pp. 193-207 (pp. 201-02).

27 In Edipo re, the updating of the material consists precisely in the fact that the 
individual psychic constellation that allows the patricide to 'return' to the present is coupled with an instrumental reason that reduces the myth to its materiality - for instance, when, instead of solving the riddle of the sphinx, Oedipus simply pushes it down off the mountain, thus becoming king.

28 This function of the character of Medea in Pasolini comes together with an analysis of the marginalization of women in the Greek polis. In this context, Nicole Loraux, Mothers in Mourning, trans. by Corinne Pache (Ithaca: Cornell University Press, 1998), pp. 9-28, has pointed out that Greek theatre in the fifth century вс had the function of compensating for this marginalization by becoming the site of feminine affects. In opposition to my approach, this rather ideologycritical side of Loraux's feminist reading means that no particular site of the political was conceded to the theatre, as I am here attempting to show is the case with the spatio-visual concept of Medea. I am grateful to Astrid DeuberMankowsky for drawing my attention to Loraux's study.

29 Birkenhauer, 'Tragödie: Arbeit an der Demokratie', p. 28. 
Bernhard Gross, 'Reconciliation and Stark Incompatibility: Pasolini's 'Africa' and Greek Tragedy', in The Scandal of SelfContradiction: Pasolini's Multistable Subjectivities, Geographies, Traditions, ed. by Luca Di Blasi, Manuele Gragnolati, and Christoph F. E. Holzhey, Cultural Inquiry, 6 (Vienna: Turia + Kant, 2012), pp. 167-86 <https://doi.org/10.37050/ci-06_10>

\section{REFERENCES}

Bazin, André, What is Cinema?, ed. by Hugh Gray (Berkeley: University of California Press, 1971) Birkenhauer, Theresia, Theater/Theorie: Zwischen Szene und Sprache, ed. by Barbara Hahn and Barbara Wahlster (Berlin: Verlag Vorwerk 8, 2008)

'Tragödie: Arbeit an der Demokratie. Auslotung eines Abstandes', Theater der Zeit, 11 (2004), pp. 27-28.

Brecht, Bertolt, 'The Modern Theatre is the Epic Theatre', in Brecht on Theatre, ed. and trans. by John Willett (New York: Hill and Wang, 1964), pp. 33-42

Deleuze, Gilles, Cinema 1: The Movement Image, trans. by Hugh Tomlinson (London: Athlone Press, 1986)

d'Ascia, Luca, 'Die Genealogie der Macht bei Pier Paolo Pasolini', in Kunst-Macht - Gewalt: Der ästhetische Ort der Aggressivität, ed. by Rolf Grimminger (Munich: Fink, 2000), pp. 193207

Fusillo, Massimo, La Grecia secondo Pasolini: Mito e cinema (Roma: Carocci, 2007)

Girshausen, Theo, Ursprungszeiten des Theaters: Das Theater der Antike (Berlin: Verlag Vorwerk 8, 1999)

Groß, Bernhard, Pier Paolo Pasolini: Figurationen des Sprechens (Berlin: Verlag Vorwerk 8, 2008)

Kappelhoff, Hermann, 'Narrative Space - Plot Space - Image Space' available at <http://www. hermann-kappelhoff.de/01/images/stories/narrative_space_onlineversion.pdf> [accessed 26 September 2011]

Kracauer, Siegfried, Theory of Film: The Redemption of Physical Reality (Oxford: Oxford University Press, 1965)

Liccioli, Edi, La scena della parola: Teatro e poesia in Pier Paolo Pasolini (Firenze: Le Lettere, 1997)

Linder, Jutta, Pasolini als Dramatiker (Frankfurt am Main: Lang, 1981)

Loraux, Nicole, Mothers in Mourning, trans. by Corinne Pache (Ithaca: Cornell University Press, 1998)

Pasolini, Pier Paolo, Teatro (Milan: Garzanti, 1995)

Rancière, Jacques, 'Aesthetics and Politics: Rethinking the Link', talk at the University of California at Berkeley, September 2002. Available at <http://www.16beavergroup.org/monday/ archives/001881.php > [accessed 11 September 2011]

The Politics of Aesthetics: The Distribution of the Sensible (London: Continuum, 2009)

Ward, David, 'Pier Paolo Pasolini and the Events of May 1968: The "Manifesto per un nuovo teatro", in Pasolini Old and New. Surveys and Studies, ed. by Zygmunt G. Barański (Dublin: Four Courts Press, 1999), pp. 321-44

Witte, Karsten, 'Das Erfinden einer neuen Schönheit: Pasolini - Körper/Orte', in Die Körper des Ketzers: Pier Paolo Pasolini (Berlin: Verlag Vorwerk 8, 1998), pp. 54-75 